\title{
Iwona Lorenc
}

https://orcid.org/0000-0003-3364-3953

Uniwersytet Warszawski

Instytut Filozofii

lorenc@cyberia.pl

\section{W POSZUKIWANIU ODWRÓCONEGO CZASU AWANGARDY PRÓBA ODCZYTANIA FENOMENU DEBORY VOGEL W KONTEKŚCIE KRYZYSU NOWOCZESNEGO DOŚWIADCZENIA}

\begin{abstract}
Abstrakt
Artykuł jest próbą rozważenia koncepcji artystycznej Debory Vogel w kontekście refleksji nad transformacjami doświadczenia późnej nowoczesności. Jedną z tych zmian, którą uważam za kluczową, jest odejście od narracyjnej linearności ku polifonicznej symultaniczności, związane $\mathrm{z}$ przeniesieniem akcentu $\mathrm{z}$ czasowych aspektów nowoczesnego doświadczenia na jego aspekty przestrzenne. Drugim kontekstem, w którym rozważam fenomen Vogel, są transformacje, które zaszły w sztuce pod wpływem awangardy - z takimi jej wiodącymi pojęciami jak symultaniczność, polifonia, zaburzenie hierarchii, brak centrum, zdarzenie, wykorzenienie, zatarcie granic między sztuką i życiem. Uważam, że pełne znaczenie wymienionych wątków staje się widoczne w sztuce neoawangardowej. Śledząc wątki sztuki neoawangardowej, wyodrębniam zmiany, które wydają się ważne z perspektywy konieczności powrotu do Vogel jako ich antycypatorki. Metoda, którą przyjmuję, zakłada szczególne rozumienie antycypacji, zgodnie z którym początek (awangarda) jest współtworzona przez jej kontynuację (neoawangardę).
\end{abstract}

\section{Slowa kluczowe}

antycypacje w sztuce, awangarda, neoawangarda, Nachträglichkeit, posthistoryzm, czasowość doświadczenia estetycznego, przestrzenność doświadczenia estetycznego

\section{WPROWADZENIE}

Czas artystycznej awangardy historycznej to również lata filozoficznych konceptualizacji zmian, jakie zachodzą w sposobie nowoczesnego doświadczania świata. Powszechnie dyskutowany wówczas „kryzys doświadczenia” wpisywany jest w różne koncepcje i dyskursy filozoficzne. Dużą operacyjną przydatność uzyskało na tym polu Diltheyowskie rozróżnienie na dwa typy doświadczeń: Erfahrung i Erlebnis; w badaniach nad kryzysem nowoczesnego doświadczenia pierwszy $\mathrm{z}$ nich ujmowany jest jako niemożliwy do realizacji projekt 
doświadczenia całościowego, drugi zaś jako równie niemożliwy do osiągnięcia ideał autentyczności wpisany w punktowe, wydarzeniowe przeżywanie świata. Obraz późnonowoczesnego, znajdującego się w stanie kryzysowego rozpadu, doświadczenia rozpinany jest między dwoma rodzajami traumy, dwoma niespełnionymi i często uznawanymi za niespełnialne, oczekiwaniami. W kulturze, w sztuce, filozofii, teorii społecznej krystalizowane są one na dwóch odległych, choć dialektycznie związanych ze sobą biegunach: jako to, co skostniałe i wyobcowane oraz jako to, co płynne i nieuchwytne.

Ów spolaryzowany obraz badań rysują zarówno Frankfurtczycy (Benjamin, Adorno) jak i Giddens, Bauman, Berman ${ }^{1}$ czy Maffesoli. Nawiasem, przykład tego ostatniego z wymienionych teoretyków każe zaznaczyć, iż wskazana polaryzacja nie zawsze ujmowana jest w aspekcie traumy. Na przykład Maffesoli czy Lyotard skłonni byliby raczej przyjmować postawę afirmacji wobec rozbicia pola współczesnego doświadczenia na wielość centrów o przeżyciowym, wydarzeniowym charakterze. W tym miejscu, ze względu na konstrukcję wywodu, interesuje mnie jednak silnie podkreślany i chyba dominujący we wskazanej literaturze problemu, aspekt traumy towarzyszącej tym dwóm biegunowym oczekiwaniom wpisanym $\mathrm{w}$ różniące się od siebie sposoby doświadczania świata przez człowieka późnej nowoczesności. Na polskim gruncie przekonująco problem ten ujmuje Anna Zeidler-Janiszewska w książce Między melancholia a żałobą: estetyka wobec przemian w kulturze współczesnej ${ }^{2}$.

W artykule będę broniła tezy, iż powyższa biegunowość dwóch różniących się między sobą sposobów reagowania człowieka późnonowoczesnego na kryzys doświadczenia ustanawia ramy dla awangardy programowo nieprzystającej do własnego czasu, odrzucającej jego linearne pojmowanie na rzecz artystycznych technik anachronizacji doświadczenia, sposobów dokonywania przesunięć zarówno w kierunku antycypacji, co i retrospekcji oraz odwracania czasowych wektorów przyszłości i przeszłości. Strategie te są kontynuowane i dopełniane przez neoawangardę. Dopiero z pozycji, które zajmuje sztuka neoawangardowa widoczne stają się awangardowe antycypacje przyszłych subwersji oraz destrukcji ustalonych hierarchii i tożsamości. O tych antycypacjach będę pisała w odniesieniu do koncepcji Debory Vogel.

\footnotetext{
${ }^{1}$ Zob. Marshall Berman, Wszystko, co stałe, rozpływa się w powietrzu. Rzecz o doświadczeniu nowoczesności, przeł. Marcin Szuster, Towarzystwo Autorów i Wydawców Prac Naukowych Universitas, Kraków 2006.

${ }^{2}$ Zob. Anna Zeidler-Janiszewska, Między melancholia a żałoba: estetyka wobec przemian w kulturze współczesnej, Wydawnictwo Instytutu Kultury, Warszawa 1996.
} 
NEOAWANGARDA JAKO ZWIEŃCZENIE I ZROZUMIENIE AWANGARDY

Polaryzacja oczekiwań nadaje późnonowoczesnemu doświadczeniu znamię niewypełnionej czasowości, wybija na nim melancholijno-nostalgiczne piętno niemożliwego projektu rozciągniętego w czasie „wycofanym”. Używam terminu „czas wycofany” z pełnym rozmysłem modyfikując interpretację kategorii Nachträglichkeit przyjętą za Freudem przez Hala Fostera w znaczeniu „spóźnionej czasowości”. Trauma towarzysząca realizacji projektów awangardowych bierze się stąd, że awangarda jako „straż przednia” wyprzedzająca swój czas skazana jest na dokonywanie wyłomu w uznanym systemie symbolicznym, że jest projektem wewnętrznie aporetycznym: wypracowuje ona warunki własnych możliwości za cenę braku przynależności do czasu, za cenę funkcjonowania w luce systemu symbolicznego oraz między dwoma rodzajami nieprzystawania do własnego czasu, między dwoma ,anachronizmami”. Jeden $\mathrm{z}$ nich to anachronizm antycypacji, drugi to anachronizm regresu. Awangarda artystyczna tyleż wyprzedza swój czas, co pozwala mu się doganiać, jest bowiem nieustającą konstatacją własnego (niemożliwego zresztą) końca jako sztuki.

Słowem, prospektywizm wpisany w projekt awangardy historycznej zawiera wskazaną wyżej ambiwalencję antycypacji i retrospekcji; krytycznego dystansu wobec tego, co zastane, ale i - „mitycznego" często zanurzenia w tym, co poprzedza doświadczenie teraźniejszości. Z tego punktu widzenia projekt awangardy jest zarazem krytyczny (często metakrytyczny) i mityczny.

Ów oscylujący ruch przemieszczeń między postawą metakrytyczną i mitycznym zanurzeniem odnajdujemy już w awangardzie historycznej; kompulsywnie powtarza go neoawangarda. Powtórzenie to nie ma jednak charakteru mechanicznej reprodukcji, lecz wzajemnie fundującej relacji. Nie ma między jedną i drugą ostrego cięcia. Nie ma próby odrodzenia sztuki awangardowej po klęsce historycznej awangardy, gdyż zakwestionować należy przekonanie o absolutnym wymiarze tej porażki.

Bliski moim poglądom w tej kwestii Hal Foster przekonująco argumentuje przeciwko tezie Bürgera mówiącej o tym, że historyczna awangarda poniosła klęskę. Wprawdzie - pisze - „dadaiści nie zdołali zniszczyć tradycyjnych kategorii sztuki, surrealiści połączyć jednostkowej transgresji z rewolucją społeczną, zaś konstruktywiści uspołecznić środków produkcji artystycznej. Była to jednak klęska heroiczna, tragiczna. Powtórzenie tej klęski przez neoawangardę to dla Bürgera gest $\mathrm{w}$ najlepszym razie patetyczny i farsowy, w najgorszym zaś cyniczny i oportunistyczny" ${ }^{3}$. Teza Fostera wyrastająca ze sprzeciwu wobec ujęcia Bürgerowskiego jest, $\mathrm{z}$ mojego punktu widzenia, dobrym punktem

\footnotetext{
${ }^{3}$ Hal Foster, Powrót realnego. Awangarda u schytku wieku, przeł. Mateusz Borowski, Małgorzata Sugiera, Towarzystwo Autorów i Wydawców Prac Naukowych Universitas, Kraków 2010, s. 37.
} 
wyjścia do ponownego odczytania projektu awangardy historycznej. Teza ta brzmi: „Neoawangarda nie tyle przekreśliła projekt historycznej awangardy, co po raz pierwszy faktycznie go pojęla"4.

Gest zerwania ciągłości dokonany przez historyczną awangardę nie powinien być traktowany dosłownie - argumentuje przytaczany autor. Nie można go interpretować w kategoriach ciągłości mononarracyjnej (jak u Hegla), lecz potrzebne nam są różne, pracujące obok siebie, modele przyczynowości, czasowości i narracji. Toteż „historyczna awangarda i neoawangarda mają podobną strukturę jako proces nieustannych protencji i retencji, jako skomplikowana sztafeta antycypowanej przyszłości i rekonstruowanej przeszłości. Obie powstały w efekcie opóźnionego działania, które eliminuje każdy prosty schemat przed i po, prostą zależność przyczyny i skutku, oryginału i powtórzenia"5.

Neoawangarda „odgrywa” anarchistyczne gesty zerwań i sprzeciwy awangardy historycznej, czasem je powoli przepracowuje (w znaczeniu, jakie Freud nadał histerycznemu odgrywaniu traumy w przepracowującym ją powtórzeniu). Awangarda rozwija się więc poprzez neoawangardowe powtórzenia, jej sens wydobywany jest $\mathrm{w}$ jej własnych opóźnionych działaniach. W pewien paradoksalny sposób można rzec za Fosterem, iż powraca ona z przyszłości.

Mechanizm opóźnionego działania Marc Jimenez nazwie „gambitem”6, posługując się tym szachowym terminem, aby oddać naturę strategii charakterystycznej dla pierwszej awangardy: strategii „odwleczonego matu”, „bomby z opóźnionym zapłonem”. Znaczenie pierwszego posunięcia konstytuowane jest przez ciąg dalszy. Duchamp jest w ujęciu Jimeneza takim modelowym szachistą wyznaczającym strategię awangardy. W 1911 roku maluje on "Graczy w szachy”, niedługo potem „Portret graczy w szachy”. W 1923 roku stawia kluczowe pytanie: „Czy można wytwarzać dzieła nie będące sztuką?”7. Jego ready mades wieńczą i zamykają system reprezentacji wypracowany przez Zachód. Uruchamiają mechanizm, o którego skuteczności świadczy choćby liczba imitacji, plagiatów, reprodukcji, jak również subtelnych, nieraz delirycznych interpretacji: od Bretona po Schwarza; od Lyotarda po de Duve`a. Reakcja na Duchampa ma charakter kompulsywnego i paradoksalnego „niekończącego się odwleczenia”. Tym, co ulega odwleczeniu, skutkiem opóźnionej czasowości, wedle której oddziałuje Duchamp, jest jego odkrywany z opóźnieniem potencjał metakrytyczny wraz z ładunkiem przysługującej jego pracom metaironii.

Pisze o tym François Lyotard w Les transformateurs Duchamp ${ }^{8}$, zauważając, iż zaistnienie Duchampa metaironicznego możliwe było dzięki przepracowaniu

\footnotetext{
${ }^{4}$ Ibidem, s. 39. Por. Peter Bürger, Teoria awangardy, przeł. Jadwiga Kita-Huber, Towarzystwo Autorów i Wydawców Prac Naukowych Universitas, Kraków 2006.

${ }^{5}$ Ibidem, s. 54.

${ }^{6}$ Marc Jimenez, La critique. Crise de l'art ou consensus culturel?, Klincksieck, Paris 1995.

${ }^{7}$ Duchamp du signe, Textes réunis par Marc Sanouillet, Paris, Flammarion, Paris 1975, s. 105.

${ }^{8}$ Por. Jean-François Lyotard, Les transformateurs Duchamps, Éditions Galilee, Paris 1977, s. 62.
} 
traumy tego wydarzenia (jako wyłomu w tradycyjnym, zrozumiałym systemie symbolicznym) przez jego późniejsze powtórzenia i transformacje. Te zaś wpisywały się $\mathrm{w}$ nowy system zapośredniczeń instytucjonalnych, w obrębie których sztuka neoawangardowa była rzutowana na ekran horyzontalnego odróżnicowania, ekran sił instytucjonalnych, politycznych, ekonomicznych. Wedle owej otwartej przez gambit Duchampa strategii, dopiero w wyniku doganiania Duchampa przez czas, który po nim nastąpił, możliwe stało się nie tylko odczytanie znaczenia jego dzieła, ale i została urzeczywistniona nowa, neokapitalistyczna strategia wobec sztuki. Rainer Rochlitz pisze o niej celnie: „Nowa strategia burżuazji modernistycznej i neokapitalistycznej polega na otwieraniu drzwi akademikom jako herosom awangardy w trosce o utrzymanie ustalonego porządku poprzez stymulowanie konsumpcji dóbr kulturalnych"9.

\section{FENOMEN VOGEL JAKO ANTYCYPACJA PRZEMIAN NOWOCZESNEGO DOŚWIADCZENIA BĘDĄCYCH UDZIAŁEM NEOAWANGARDY: OD LINEARNOŚCI KU POLIFONICZNEJ RÓWNOCZESNOŚCI}

Neoawangarda to, z jednej strony, produkt działania owej maszynerii przemieszczeń stymulowanych przez politykę, ekonomię, kulturową instytucjonalizację, $\mathrm{z}$ drugiej zaś urzeczywistnienie tendencji antycypowanych $\mathrm{w}$ awangardzie historycznej. Wśród nich za najważniejsze, wpisujące się w najogólniejszą charakterystykę przemian późnonowoczesnego doświadczenia uważam przesunięcia od linearności narracyjnej ku polifonicznej równoczesności, co ma związek z wypieraniem czasowych aspektów doświadczenia nowoczesnego przez jego aspekty przestrzenne; Arthur Danto ${ }^{10}$ zdaje się podobnie postrzegać ważność tej tendencji, gdy rozpoznaje w późnej nowoczesności ruch od narracyjności sztuki historycznej do posthistoryzmu; pojęcia kluczowe posthistorycznego etapu w sztuce to: symultaniczność, polifonia, zrównanie hierarchii, brak centrum, wydarzeniowość, wykorzenienie, zatarcie granic między sztuką a życiem.

Każde z tych pojęć dałoby się z powodzeniem zastosować do awangardy dwudziestolecia międzywojennego. Każde $\mathrm{z}$ nich mogłoby być kluczem otwierającym rozumienie dokonań artystycznych i teoretycznych Debory Vogel. Rozumienie możliwe dzięki czasowi, który je dogonił i pozwolił, abyśmy określili je mianem antycypacji współczesnej neoawangardy.

Myślenie Vogel o sztuce, doświadczeniu estetycznym w kontekście namysłu nad stanem nowoczesnego doświadczenia nabiera dziś zadziwiającej aktu-

\footnotetext{
${ }^{9}$ Rainer Rochlitz, Subversion et subvention. Art Contemporain et argumentation esthétique, Gallimard, Paris 1994, s. 27.

${ }^{10}$ Por. Arthur C. Danto, Po końcu sztuki. Sztuka wspótczesna i zatarcie się granic tradycji, thum. Mateusz Salwa, Towarzystwo Autorów i Wydawców Prac Naukowych Universitas, Kraków 2013.
} 
alności. Jeśli antycypuje ono późniejsze przeobrażenia, które wieńczone są przez neoawangardę, to w wyłożonym wyżej rozumieniu antycypacji. Antycypacja - powtórzę raz jeszcze - to odwrócone powtórzenie; termin służący do wydobycia dynamiki minionych doświadczeń. Nie można zignorować faktu, że nasz dzisiejszy teoretyczny wgląd w sztukę artystów awangardowych jest mocno obciążony (lub jak kto woli, wzbogacony) doświadczeniami obcowania ze sztuką neoawangardową. W awangardzie, z której wyrasta i do której odnosi się neoawangarda - poszukujemy zatem odpowiednika naszych teraźniejszych oczekiwań, tego co się powtarza w owym retrospektywnym oglądzie. Tylko w ten sposób, tylko patrząc wstecz można odkryć antycypacyjny potencjał tej sztuki. Ogląd ten odbywa się wbrew naturalnemu rozpoznaniu ruchu powtórzenia, wbrew potocznej intuicji traktującej to, co aktualne jako późniejsze od tego, co przeszłe i wcześniejsze od tego, co przyszłe. W tym ujęciu wektor czasowy powtórzenia ulega odwróceniu: to, co minione rozpatrywane jest jako powtórzenie tego, co aktualne w tym, co przeszłe.

Wypada zarazem zaznaczyć, iż pojęcie antycypacji, którym się posługuję, nie jest kluczem-wytrychem otwierającym i obiecującym pełną interpretację przeszłości. Wręcz odwrotnie, pozwala ono wyznaczyć pewną granicę dostępności, lub raczej oporu, jaki przeszłe doświadczenia ludzi zanurzonych we własnym czasie stawiają naszym interpretacyjnym zapędom. Pod tym względem jako figura źródłowego anachronizmu wpisanego w każdą interpretację doświadczenia estetycznego w jego faktycznym, związanym ze swoim czasem wymiarze, antycypacja (przynajmniej w znaczeniu, które wydobywam) jest figurą czasu niemożliwego do odzyskania. Przekonująco pisze o tym Didi-Huberman, w którym postrzegam swego sojusznika:

Oto wielkość i nędza historyka: jego pragnienie zawsze będzie zawieszone między uporczywą melancholią przeszłości jako przedmiotu straty a kruchym zwycięstwem przeszłości jako przedmiotu odnalezionego, przedmiotu przedstawienia (...) Mamy jeszcze kilka zabytków, ale nie znamy świata, który je stworzył; mamy jeszcze kilka słów, ale nie znamy już wypowiedzi, w których się pojawiały; mamy jeszcze kilka obrazów, ale nie znamy już spojrzeń, które nadawały im cielesność; mamy opis rytuałów, ale nie znamy już ich fenomenologii ani dokładnej wartości ich oddziaływania. Co to oznacza? Że każda przeszłość jest definitywnie anachroniczna - istnieje i tworzy się tylko poprzez figury, które jej nadajemy; istnieje zatem tylko w operacjach „teraźniejszości wspomnienia", teraźniejszości obdarzonej wspaniałą lub niebezpieczną mocą uobecniania, a także, po tym uobecnieniu, mocą jej opracowania i przedstawienia ${ }^{11}$.

${ }^{11}$ Georges Didi-Huberman, Przed obrazem. Pytanie o cele historii sztuki, przeł. Barbara Brzezicka, Wydawnictwo Słowo/Obraz Terytoria, Gdańsk 2011, s. 31. 
Nie chodzi zatem o to, aby poprzez figurę antycypacji odtworzyć minione projekty i zawarte w nich oczekiwania, zakładając iż są one przeniesione w czasie do teraźniejszości. Chodzi raczej o to, iż antycypacje tworzone są przez teraźniejsze oczekiwania, które ze swej strony wyrosły z gleby minionych doświadczeń, a do których nie mamy już pełnego dostępu. Fenomen Debory Vogel zawiera nie tylko aspekt tajemnicy jej niemożliwego dziś do pełnego odtworzenia i interpretacji życia i twórczości, ale i aspekt jej ponownego odkrycia przez tych, którzy zdają sprawę z aktualnego stanu oczekiwań artystów i filozofów sztuki. Potrzeba ponownego odczytania Vogel jest więc ważnym polem samoobserwacji, istotnym zadaniem dla tych, którzy pracują nad zrozumieniem stanu naszego dzisiejszego doświadczenia.

Rzecz jest zatem do szerszego i głębszego przebadania. W wąskich ramach, na jakie pozwala mi forma tego szkicu nie próbuję nawet wnikać w mroki żywego doświadczenia, zanurzenia w czas, który był udziałem Vogel. Ograniczę się do wybiórczego zabiegu wydobycia kilku istotnych rysów jej myślenia o sztuce i doświadczeniu nowoczesnym; tych, które eksponuje światło namysłu nad neoawangardą.

Pójdę tropami wyznaczonymi przez neoawangardę, co pozwoli mi ustawić światło reflektora. Światło to pozwoli naświetlić następujące przesunięcia, które wydają mi się ważne z punktu widzenia potrzeby powrotu do Vogel i które we wstecznym ruchu odczytania myśli polskiej awangardzistki zmierzają ku wydobyciu istotnych dla niej zjawisk, przesunięć znaczeniowych i odpowiadających im kategorii.

Ważnym motywem jest zwrócenie się ku doświadczeniu codzienności miasta jako laboratorium nowych reguł pola semiotycznego sztuki; chodzi przede wszystkim o ważne dla Vogel kategorie montażu, powtórzenia/serii, rozproszenia, konkretu/elementu życiowego, uprzestrzennienia czasu.

Zacznę zatem - zgodnie z przyjętą metodą „czasu odwróconego” - od charakterystyki kontekstu neoawangardy. Hal Foster zauważa, iż w wyniku przeniknięcia znaku przez kapitał (w związku z upowszechnieniem kapitału rynkowego, procesami nieograniczonych ekwiwalencji) w późnonowoczesnym doświadczaniu świata następuje „semiotyczne przesunięcie z porządku indeksu (tj. stałej oznaki tożsamości) do porządku znaku jako relatywnej mobilności możliwych pozycji" "12. Sztuka i filozofia, począwszy od zwrotu tekstowego z końca lat siedemdziesiątych wieńczą i odzwierciedlają te procesy. Zbieżność między porządkiem semiotycznym późnej nowoczesności a epoką kapitalizmu monopolistycznego kieruje uwagę filozofów ku krytyce referencyjnego modelu języka, i powoduje wprowadzenie na jego miejsce otwartego modelu zakładającego nieskończoną grę znaczeń.

${ }^{12}$ Hal Foster, Powrót realnego..., s. 99. 
Baudrillard i Jameson akcentują przejście od językoznawstwa strukturalnego do semiotyki poststrukturalnej (gdzie istotne są trzy momenty: ujęcie w nawias referenta, uwolnienie znaczącego, zamienność znaczonego i znaczącego). Reakcją na rozpad znaku jest postępująca abstrakcja znaku w sztuce eksperymentalnej XX wieku. Sztuka amerykańska lat sześćdziesiątych i siedemdziesiątych rejestruje i przepracowuje artystycznie te procesy rozpadu i abstrakcji. Następuje fragmentacja języka sztuki, jej wewnętrzny sprzeciw wobec uprzedmiotowienia języka (konceptualizm), wreszcie indeksalne, czasoprzestrzenne ugruntowanie znaczonego ustępuje miejsca alegorycznemu rozproszeniu, grze znaczących. Niszczony jest autorytet autora, podmiotu, humanistycznych formuł człowieczeństwa, oryginału, autonomii sztuki. Dobrym przykładem powyższych procesów jest sztuka zawłaszczenia. Nurty sztuki zawłaszczenia lat siedemdziesiątych i osiemdziesiątych (Sherrie Levine, Louise Lawler, Barbara Bloom, Silvia Kolbovski) dokonują rozerwania znaku oraz jego związku z mitycznym osadzeniem, na nowo wpisują go w krytyczny montaż, a następnie ów sztuczny, skonstruowany mit puszczają w obieg kulturowy.

Charakterystyczna dla lat osiemdziesiątych ,estetyka spektaklu” i sztuka zawłaszczenia traktowały działania artystyczne jako oderwane znaczące, łatwo poddające się manipulacji i prawom rynku. Procesy uwalniania znaku w sposób widoczny związane są ze wspomnianymi już procesami instytucjonalizacji sztuki. Zdaniem Fostera sprzyjają one umacnianiu się „sztuki cynicznego rozumu”. Na przykład obrazy Sherrie Levine, cytujące abstrakcyjne prace Franka Stelli, Roberta Rymana, Brice'a Mardena, w otwarty, cyniczny sposób eksponowały fakt zawłaszczenia, ,swoje nieudane lub wymuszone fałszerstwo"13. Sztuka cynicznego rozumu idzie dalej niż zawieszający reprezentację abstrakcjonizm: zastępuje reprezentację seryjną produkcją obrazów i rzeźb-towarów w warunkach zaawansowanego kapitalizmu. Pop-art z Andy Warholem na czele, oraz nurt neo-pop oznaczają zwrot ku seryjnej produkcji obrazów, charakterystyczną dla „sztuki cynicznego rozumu” zgodę na procesy rynkowej i kulturowej instytucjonalizacji, a zarazem krytyczny wobec nich dystans, dodatkowo wzmacniający profity z własnej przynależności do owych procesów. Koons i Steinbach, prezentując dzieło sztuki jako towar i zastępując utraconą aurę fałszywą aurą towaru, eksponują luksusową wartość sztuki, a zarazem sami czerpią z niej korzyści.

Nie ma sensu mnożyć dalej przykładów. Widać wyraźnie, że konsekwencje uabstrakcyjnienia znaku, rozbicia i dehierarchizacji pola semiotycznego, których doświadcza sztuka neoawangardowa, są zapośredniczone przez rynkowe procesy instytucjonalizacji sztuki.

${ }^{13}$ Por. Hal Foster, Powrót realnego..., s. 123. 
Sztuka i estetyka polskiego okresu międzywojennego, słabo dotknięte jeszcze wirusem cynicznego rozumu, dalekie były od świadomości owych konsekwencji. W pewien sposób je jednak antycypowały. Analizując twórczość poetycką Vogel Paweł Mościcki zwraca uwagę na dystans, z jakim poetka traktuje temat „gry między iluzją reklamy a deziluzją nowoczesnego życia”"14. Trafnie określa ją jako autodemonstrację mechanizmu reklamy oraz rytmu filmowej projekcji. Vogel - dodajmy - miała świadomość ekranu w jego podwójnej roli; chodzi tu „ekran” w znaczeniu antycypującym wspomnianą przez Fostera neoawangardową estetykę spektaklu, ale też o „ekran” w znaczeniu mechanizmów ekonomiczno-kulturowego zapośredniczenia doświadczeń, prowadzącego do ich dehierarchizacji i policentryzacji.

Miasto jest w tym zakresie świetnym polem obserwacji zjawisk i procesów, na które jest Vogel szczególnie wrażliwa. Jest ona świadoma reprezentatywnej, ale też kształtującej roli doświadczenia miasta dla doświadczenia nowoczesności jako takiego. Pisze: ,jak dawniej przyroda, tak dziś miasto i komórki jego: fabryki, warsztaty pracy i wnętrza zdolne są dostarczyć mu elementów do przeróbki myślowej i formalnej”'15. To w środowisku miejskim, jak nigdzie indziej, zderzają się dwa niemożliwe do realizacji modele doświadczeń. Za Diltheyem nazwałam je na wstępie modelami Erfahrung i Erlebnis (jako modelami całościowania oraz punktowego przeżywania świata). U Vogel nostalgiczno-melancholijne poszukiwania w codzienności życia Lwowa śladów scalających, choć niemożliwych do odzyskania, mitycznych podstaw doświadczenia wspólnoty (,lwowska juderia”) zderzają się z doświadczeniem miasta w ,przekroju poprzecznym", w Augenblick; w czasie zatrzymanym, zastąpionym przestrzennym współwystępowaniem poszczególnych, izolowanych, idiomatycznych Erlebnissen (przywołać należy w tym miejscu jej fascynacje pracami Henryka Strenga).

Martin Jay tak formułuje owo napięcie cechujące współczesny sposób doświadczania świata, a które - można śmiało zauważyć - było antycypowane w pracach Vogel:

$\mathrm{Z}$ jednej strony (...) «doświadczenie» (w jednym ze znaczeń Erfahrung) nie jest już możliwe, a $\mathrm{z}$ drugiej [można - I.L.] dopuszczać przeciwstawną tezę, mówiąca, że żyjemy $\mathrm{w}$ prawdziwym społeczeństwie przė̇ycia [Erlebnisgesellschaf $]^{16}$. Ta dwoistość pozwala nam zarazem odwolywać się do doświadczenia, jakby było ono sprawą przeszłości, i być go «spragnionym», jakby było ono czymś, czym można się będzie cieszyć dopiero w przyszłości ${ }^{17}$.

\footnotetext{
${ }^{14}$ Paweł Mościcki, Montaż, miasto, monotonia, w: Montaże. Debora Vogel i nowa legenda miasta, red. Andrij Bojarov, Paweł Polit, Karolina Szymaniak, Muzeum Sztuki w Łodzi, Łódź 2017, s. 195.

${ }^{15}$ Debora Vogel, Mieszkanie w swej funkcji psychicznej i społecznej, w: Montaże..., s. 300.

${ }^{16}$ Cytowany tu Martin Jay odwołuje się do sformułowania Gerharda Schulze z Die Erlebnisgesellschaft: Kultursoziologie der Gegenwart, Campus Verlag, Frankfurt 1992.

${ }^{17}$ Martin Jay, Pieśni doświadczenia. Nowoczesne amerykańskie i europejskie wariacje na uniwersalny temat, przeł. Agnieszka Rejniak-Majewska, Towarzystwo Autorów i Wydawców Prac Naukowych Universitas, Kraków 2008, s. 29.
} 

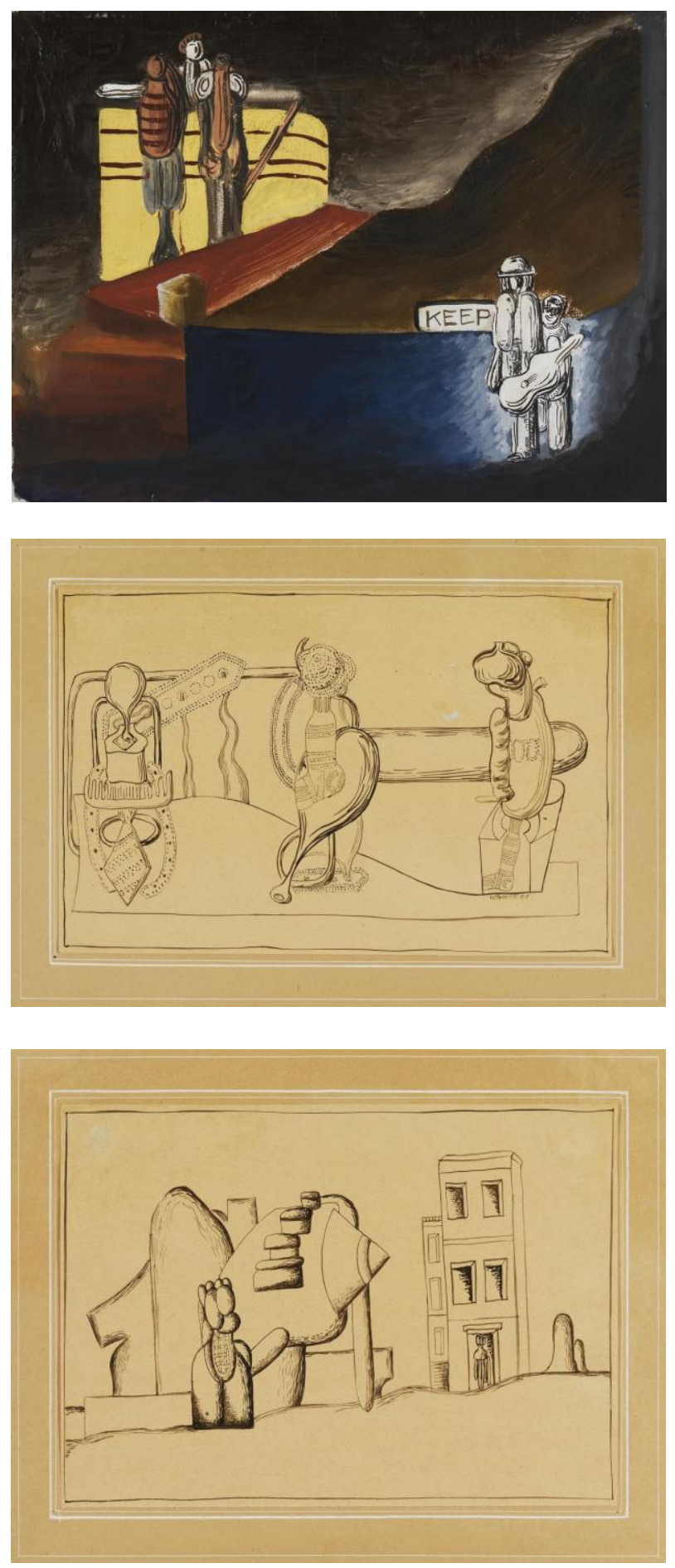

Il. 1. Henryk Streng (Marek Włodarski), Keep, 1929-1930, tempera, papier, $23 \times 31 \mathrm{~cm}$, Muzeum Sztuki w Łodzi.

Il. 2. Henryk Streng (Marek Włodarski), Rozmowa przedmiotów, 1929, sepia, papier, 21 x $34 \mathrm{~cm}$, Muzeum Sztuki w Łodzi.

Il. 3. Henryk Streng (Marek Włodarski), Pejzaż surrealistyczny, 1929, sepia, papier, 30,5 x $45 \mathrm{~cm}$, Muzeum Sztuki w Łodzi. 
Il. 4. (z prawej) Henryk Streng (Marek Włodarski), Kompozycja surrealistyczna (malarz), 1929, sepia, papier, 33 x $21 \mathrm{~cm}$, Muzeum Sztuki w Łodzi.
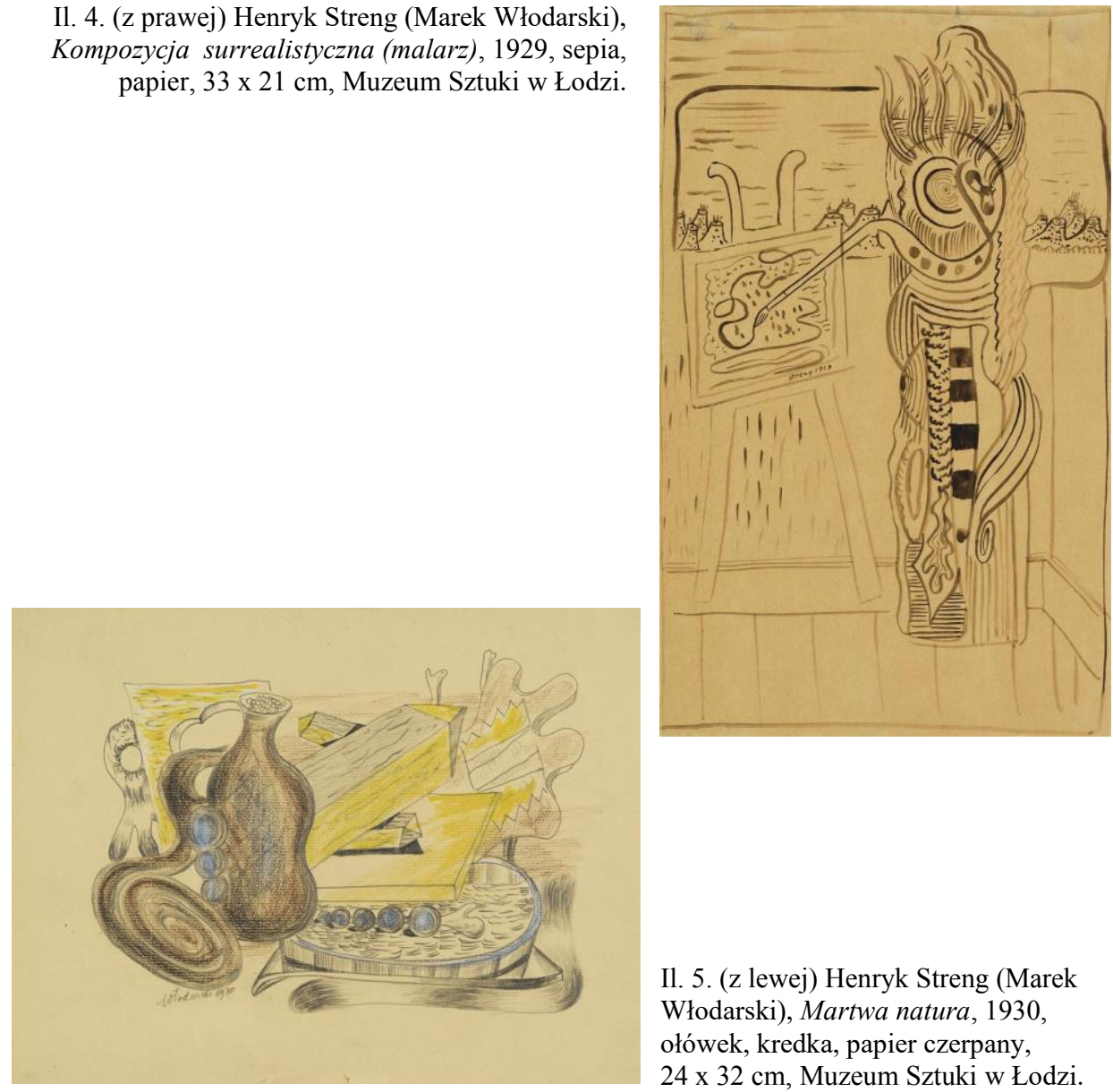

Il. 5. (z lewej) Henryk Streng (Marek Włodarski), Martwa natura, 1930, ołówek, kredka, papier czerpany, 24 x 32 cm, Muzeum Sztuki w Łodzi.

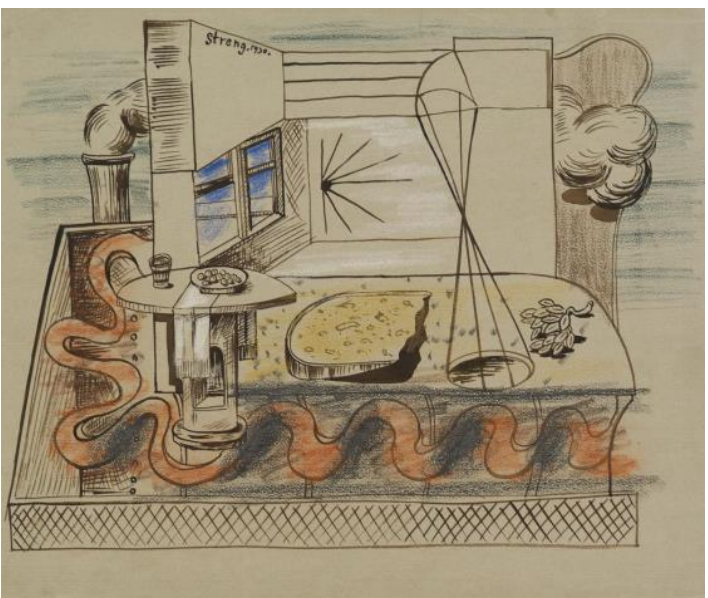

Il. 6. Henryk Streng (Marek Włodarski), Wnętrze, 1930, sepia, kredka, papier, 26,5 x $31 \mathrm{~cm}$, Muzeum Sztuki w Łodzi. 
Chodzi więc o to, co skonstatują w odniesieniu do doświadczeń ostatnich dziesięcioleci tacy badacze, jak Anthony Giddens: wykorzenienie, obcość, nieprzystawanie do własnego czasu, niezbywalna anachroniczność identyfikacji. Doświadczenie wielkiego miasta, o którym pisze Vogel w swych artykułach, stymuluje to poczucie wykorzenienia również w sensie przestrzennym (lęk przed pustą przestrzenią); poprzez mechanizację i tempo codziennego życia dehumanizuje nowoczesny podmiot.

Miasto nie tylko dehumanizuje i depersonifikuje. Jego „szybkość i ruch przechodzą w monotonię"18 - zauważa Debora Vogel. Monotonia jako „struktura rzeczywistości" to nic innego, jak semiotyczne zrównanie, dehierarchizacja. Warunki demontażu istniejących znaczeń i montowania nowych całości tkwią w rzeczywistości wielkiego miasta, poddanego prawom rynku, w jego codzienności rozproszonych, symultanicznych doświadczeń.

„Chodzona filozofia ulicy” oznacza świadome usunięcie się z pozycji centrum $^{19}$. Zdaje z niego sprawę sztuka awangardowa, o której pisze i którą jest zafascynowana Vogel. Techniki montażu (szczególnie fotomontażu) i kolażu zdają się samoistnie wyrastać z życia wielkiego miasta, rodzą się z jego doświadczeń przestrzeni, dehierarchizacji, napięć między stabilnością i dynamiką, zamknięciem w tym co prywatne i przeżyciowe (kubicznej przestrzeni mieszkania) a przyprawiającym o poczucie zagubienia i wyobcowania doświadczeniem wielkich przestrzeni publicznych.

W powyższej funkcji miasto jest przez polską awangardzistkę interpretowane przy pomocy podobnych figur wyobraźni, jakie stosuje ona wobec kompozycji przestrzeni $\mathrm{w}$ malarstwie i rzeźbie (konstruktywizm, abstrakcjonizm, unizm). W tekście o Henryku Strengu jako malarzu konstruktywizmu znajdujemy zdanie będące znakomitym wyłożeniem przez Vogel jej własnych założeń światopoglądowo-filozoficznych: w warunkach zaawansowanego kapitalizmu, zwłaszcza w doświadczeniu miasta ,została zniwelowana granica między materią a człowiekiem, a człowiek staje się manekinem, podlegającym nieuchronnej regule życia" 20 . U Légera ciało ludzkie powiela rytm maszyny - zauważa autorka. U Strenga jego wyobrażenie doprowadza „do samego końca ostateczny sens figury geometrycznej i maszynowego tempa, którym jest nieporadność i rezygnacja"21. Ujęcie przez Vogel sensu, jaki mimo wszystko awangardziści lokują w zjawiskach umaszynowienia, dehumanizacji nowoczesnego doświadczenia, zapowiada późniejsze demonstracje neoawangardy i pozwala snuć analogie do postawy rezygnacji i zgody na dehumanizację i odpodmiotowienie,

\footnotetext{
${ }^{18}$ Por. Debora Vogel, Montaż literacki, w: Montaże..., s. 394.

${ }^{19}$ Por. Karolina Szymaniak, Trzecia dzielnica? Etniczność, deterytorializacja, montaż, w: Montaże..., s. 266-267.

${ }^{20}$ Debora Vogel, Henryk Streng. Malarz konstruktywizmu, w: Montaże..., s. 365.

${ }^{21}$ Ibidem.
} 
o jakiej pisał Gianni Vattimo (jego kategoria „Verwindung” oddaje połączenie postaw pogodnej zgody, ale i rozpaczy rezygnacji).

Konstatacja dehumanizacji i odpodmiotowienia zostaje przez Vogel rozciągnięta na sztukę. Tak, jak doświadczenie miasta jest laboratorium doświadczenia nowoczesnego, jego „kondensacją”, tak „,rzeźba jest jak gdyby kondensacją przestrzeni, jej konkretyzacją, zatrzymaniem się na chwilę, bez wyrwy w ciągłości, jest kontynuacją przestrzeni samej”"22. Jest konkretem, tak jak konkretem jest obraz konstruktywistyczny czy unistyczny. W tekście o sztuce abstrakcyjnej odniesienia przedmiotowe sztuki nazywa autorka „montażu literackiego" maską, którą należy zdjąć, a czynią to abstrakcjoniści i radykalizujący abstrakcjonizm uniści. Pożądana przez artystę ,jedność miejsca i form sztuki (rzeźby z przestrzenią, form malarskich z prostokątną płaszczyzną płótna)" ${ }^{23}$ niweluje odróżnienie estetyczne (różnicę miedzy sztuką i życiem), sytuuje doświadczenie estetyczne w luce systemu symbolicznego, unieważnia odniesienia tematyczne i znaczenia, odkrywa ukrytą pod nimi sieć napięć budowanych przez samą przestrzeń, która „żąda kształtów”. Nie jest to więc struktura czystych negacji. Nawet negując przedmiotowość jako taką, sztuka zawsze pozostanie odpowiedzią na ,żądanie kształtów”.

Lektura tych wątków, przepuszczona przez filtr neoawangardy, choćby wypowiedzi minimalistów, raz jeszcze wskazuje na wyjątkową przenikliwość analiz Vogel. Wykraczają one poza modernistyczne ramy. Jak wskazuje Foster za Juddem i Morrisem, „minimaliści starają się odkryć i pokazać przedmiotowość jako taką, podczas gdy sztuka późnego modernizmu chciała ją zniszczyć lub zawiesić. W tym przypadku (...) rozstrzygającym elementem jest ksztalt. Choć nie stanowi on podstawowej cechy rzeźby (jak chciał wcześniej Morris), to jednak jest istotną cechą jej systemu przedstawiającego" ${ }^{24}$. Lektura tych zbieżnych z wypowiedziami Vogel wątków, aż się prosi o analizę fenomenologiczną. Podobną do tej, jaką robi Foster w odniesieniu do minimalizmu.

\section{UWAGI KOŃCOWE}

Wąskie ramy niniejszej wypowiedzi nie pozwalają jednak na tak szerokie dygresje. Każą one w tym miejscu zawiesić dalsze próby odczytania prac polskiej autorki przez pryzmat neoawangardy. Zaznaczę tylko, że tematem równie godnym dalszego rozwijania byłby $w$ tej perspektywie wątek etnograficzny: badanie realiów życia społeczności miejskiej, zwłaszcza diaspory żydowskiej i sztuki z niej wyrastającej poza - charakterystycznym dla modernizmu - mitem

\footnotetext{
${ }^{22}$ Debora Vogel, Kompozycja przestrzeni, w: Montaże..., s. 305.

${ }^{23}$ Debora Vogel, O sztuce abstrakcyjnej, w: Montaże..., s. 372.

${ }^{24} \mathrm{Hal}$ Foster, Powrót realnego..., s. 74.
} 
prymitywizmu i egzotyzmu, z pozycji, którą można by w duchu neoawangardowych, krytycznych nurtów etnograficznych nazwać pozycją dialektyki dystansu i bliskości. Również ten wątek, po rozpracowaniu, na co nie ma tu już miejsca, znakomicie ilustrowałby przynależność myśli Vogel do przestrzeni rozpiętej między metakrycyzmem a mitycznym zanurzeniem, o którym była mowa w pierwszych partiach niniejszego eseju.

Fenomen Vogel z pełnym rozmysłem został w niniejszym szkicu potraktowany dość instrumentalnie: był dla mnie próbą sprawdzenia skuteczności „wstecznego", zgodnego z logiką Nachträglichkeit, odczytania tego, co w linearnym porządku czasu wcześniejsze, przez pryzmat tego, co późniejsze. Rozumienie antycypacji, jakie zastosowałam w niniejszym tekście, kryje za sobą założenie, że początek jest współtworzony przez ciąg dalszy. Poprzez postrzeganie minionych zjawisk jako antycypacji tego, co jest, dokonujemy inkorporacji elementów aktualnego doświadczenia teraźniejszości w oddalający się nurt przeszłości, próbujemy pokonać anachroniczność naszych kulturowych sposobów wnikania w przeszłość. Poszukiwanie antycypacji w tym, co minione i do czego z zasady nie mamy dostępu, odpowiada dążeniu do scalania czasu ponad wpisanym $\mathrm{w}$ doświadczenie historii mechanizmem anachronizacji, jest przejawem tęsknoty za utraconą formułą całościującego doświadczenia jako Erfahrung wbrew partykularyzacji i rozproszeniu doświadczeń charakterystycznym dla naszej współczesności.

\section{BIBLIOGRAFIA}

Berman Marshall, Wszystko, co stałe rozplywa się $w$ powietrzu. Rzecz o doświadczeniu nowoczesności, thum. Marcin Szuster, Towarzystwo Autorów i Wydawców Prac Naukowych Universitas, Kraków 2006.

Bürger Peter, Teoria awangardy, przeł. Jadwiga Kita-Huber, Towarzystwo Autorów i Wydawców Prac Naukowych Universitas, Kraków 2006.

Danto Arthur Coleman, Po końcu sztuki. Sztuka wspótczesna i zatarcie się granic tradycji, przeł. Mateusz Salwa, Towarzystwo Autorów i Wydawców Prac Naukowych Universitas, Kraków 2013.

Didi-Huberman Georges, Przed obrazem. Pytanie o cele historii sztuki, przeł. Barbara Brzezicka, Wydawnictwo Słowo/Obraz Terytoria, Gdańsk 2011.

Duchamp du signe, Textes réunis par Marc Sanouillet, Paris, Flammarion, Paris 1975.

Foster Hal, Powrót realnego. Awangarda u schyłku wieku, przeł. Mateusz Borowski, Małgorzata Sugiera, Towarzystwo Autorów i Wydawców Prac Naukowych Universitas, Kraków 2010.

Jay Martin, Pieśni doświadczenia. Nowoczesne amerykańskie i europejskie wariacje na uniwersalny temat, przeł. Agnieszka Rejniak-Majewska, Towarzystwo Autorów i Wydawców Prac Naukowych Universitas, Kraków 2008.

Jimenez Marc, La critique. Crise de l'art ou consensus culturel?, Klincksieck, Paris 1995.

Lyotard Jean-François, Les transformateurs Duchamp, Éditions Galilee, Paris 1977.

Montaże. Debora Vogel $i$ nowa legenda miasta, red. Andrij Bojarov, Paweł Polit, Karolina Szymaniak, wyd. Muzeum Sztuki w Łodzi, Łódź 2017. 
Rochlitz Rainer, Subversion et subvention. Art contemporain et argumentation esthétique, Paris, Gallimard, 1994.

Schulze Gerhard, Die Erlebnisgesellschaft: Kultursoziologie der Gegenwart, Campus Verlag, Frankfurt 1992.

Zeidler-Janiszewska Anna, Między melancholia a żałobą: estetyka wobec przemian $w$ kulturze wspótczesnej, Wydawnictwo Instytutu Kultury, Warszawa 1996.

\section{IN SEARCH OF THE INVERTED TIME OF AVANT-GARDE AN ATTEMPT TO READ THE PHENOMENON OF DEBORA VOGEL IN LIGHT OF THE MODERN CRISIS OF EXPERIENCE}

This article considers the principles of Debora Vogel's artistic project in the context of reflecting on the transformations of the late modern experience. Among the transformations, the one I consider key is the shift from narrative linearity to polyphonic simultaneity which is related to the displacement of temporal aspects of modern experience by spatial ones. The second context in which I consider Vogel's work are transformations which took place in art as a consequence of the avant-garde - its signature concepts including simultaneousness, poliphony, breakdown of hierarchy, lack of a centre, event, uprootedness, blurring of boundaries between art and life. I claim that the full significance of the above-mentioned transformations becomes visible in neoavant-garde art. Following in the tracks of neo-avant-garde art, I bring out the shifts which appear to be important from the perspective of a necessity to return to Vogel as its anticipator. The method I adopt assumes a particular understanding of anticipation, according to which the beginning (avant-garde) is co-created by its continuation (neo-avant-garde).

\section{Keywords}

anticipations in art, avant-garde, neo-avant-garde, Nachträglichkeit, posthistoricism, temporality of aesthetic experience, spatiality of aesthetic experience 